\title{
Biofumigation for the Control of Vegetables Soilborne Pathogens in Some non-Temperate Climate Countries
}

\author{
Mohamed Besri* \\ Hassan II Institute of Agronomy and Veterinary Medicine, Rabat, Morocco
}

\begin{abstract}
ARTICLE INFO
Article Type: Review Article

Keywords:

Biofumigation

Methyl bromide

Montreal Protocol

soilborne pathogens,

Developing (A5) countries,

Timeline:

Received: September 10, 2021

Accepted: October 10, 2021

Published: November 15, 2021

Citation: Besri M. Biofumigation for the Control of Vegetables Soilborne Pathogens in Some nonTemperate Climate Countries. Glob J Agric Innov Res Dev. 2021; 8: 140-152.
\end{abstract}

DOl: https://doi.org/10.15377/2409-9813.2021.08.11

\begin{abstract}
Soil-borne pathogens (SBPs) significantly reduce the yield and quality of crops worldwide. In the past, their control was principally accomplished by using soil fumigants such as methyl bromide (MB). However, this fumigant which is a powerful ozone-depleting substance, has completely been phased out under the Montreal Protocol (MP). New chemicals and non-chemical alternatives to MB, including biofumigation, have been actively researched, developed, and commercially adopted worldwide. This review seeks to provide the status of biofumigation for the control of SBPs in some non-temperate climate zones referred to in this paper as Article 5 countries or developing countries according to the Montreal Protocol (MP) classification. The review will first define "the non-temperate climate zone," list the countries belonging to this zone, focus on the role and importance of the MP in phasing-out $\mathrm{MB}$, and in searching and commercially adopting alternatives including biofumigation to this fumigant. It also describes the biofumigation techniques reported and used, reports its efficacy/inefficacy to manage SBPs in some non-climate temperate countries, insists on the place it must have in an IPM program to increase its efficacy, and finally, lists the collaboration and the research needed to further develop and commercially adopt this technology in non-temperate climate countries.
\end{abstract}

*Corresponding Author Email:mohamedbesri@gmail.com,m.besri@iav.ac.ma Tel: +212 664603721

(c) 2021 Mohamed Besri. Published by Avanti Publishers. This is an open access article licensed under the terms of the Creative Commons Attribution Non-Commercial License which permits unrestricted, non-commercial use, distribution and reproduction in any medium, provided the work is properly cited. (http://creativecommons.org/licenses/by-nc/4.0/) 


\section{Introduction}

Soil-borne pathogens (SBPs) and particularly plant-parasitic nematodes (PPNs) significantly reduce the yield and quality of crops worldwide. PPNs are considered one of the major limiting factors in vegetable production. They cause an estimated crop yield loss of $14.6 \%$ in non-temperate climate zones (tropical and sub-tropical countries) and losses of $8.8 \%$ in temperate zones countries [1].

In the past, control of soil-borne pathogens of vegetable crops was principally accomplished using soil fumigants such as methyl bromide (MB) [2]. Due in large part to its adverse effect on the Earth's ozone layer, MB has been phased out of agricultural uses [2,3]. Replacement fumigants such as 1, $3 \mathrm{D}$, chloropicrin, dazomet, metam sodium, methyl iodide, fluensulfone, DMDS, and others are available. However, there are problems associated with their use [3]. The need to phase out MB fumigant under the Montreal Protocol, together with requirements from consumers, market chains as well as restrictions imposed on many chemicals around the world, encouraged the search for non-chemical options that may provide a longer-term and more sustainable approach to soil pest management [3]. One of these non-chemical alternatives which are becoming increasingly popular is biofumigation [1,4-6].

This review seeks to provide the status of biofumigation for the control of SBPs in some non-temperate climate countries referred to in this paper as developing or A5 countries according to the Montreal Protocol countries classification [7]. The review will 1) describe briefly the climate zones, 2) present the role of the Montreal Protocol (MP) in searching and implementing alternatives to MB, including biofumigation in non-temperate zone countries, 3) report its efficacy/inefficacy to manage SBPs in non-climate temperate countries 4) insist on the place it must have in an IPM program to increase its efficacy and finally, 5) report the research needed to develop further and commercially adopt this technology in non-temperate climate countries.

\section{2. “Climate Zones": Definition}

Climate zones are areas with distinct climates. They are belt-shaped and circular around the Earth and are classified using different climatic parameters such as temperature (diurnal and night, annual, mean), humidity, precipitation, wind direction, and speed etc. There are four major climate zones (Figure 1): Tropical from $0^{\circ} \mathrm{C}-23$. $5^{\circ} \mathrm{C}$ (between the tropics), Subtropical from $23.5^{\circ} \mathrm{C}-40^{\circ} \mathrm{C}$, Temperate from $40^{\circ} \mathrm{C}-60^{\circ} \mathrm{C}$ and Cold from $60^{\circ} \mathrm{C}-90^{\circ} \mathrm{C}$. The non-temperate climate zones are, therefore, tropical and subtropical [8].

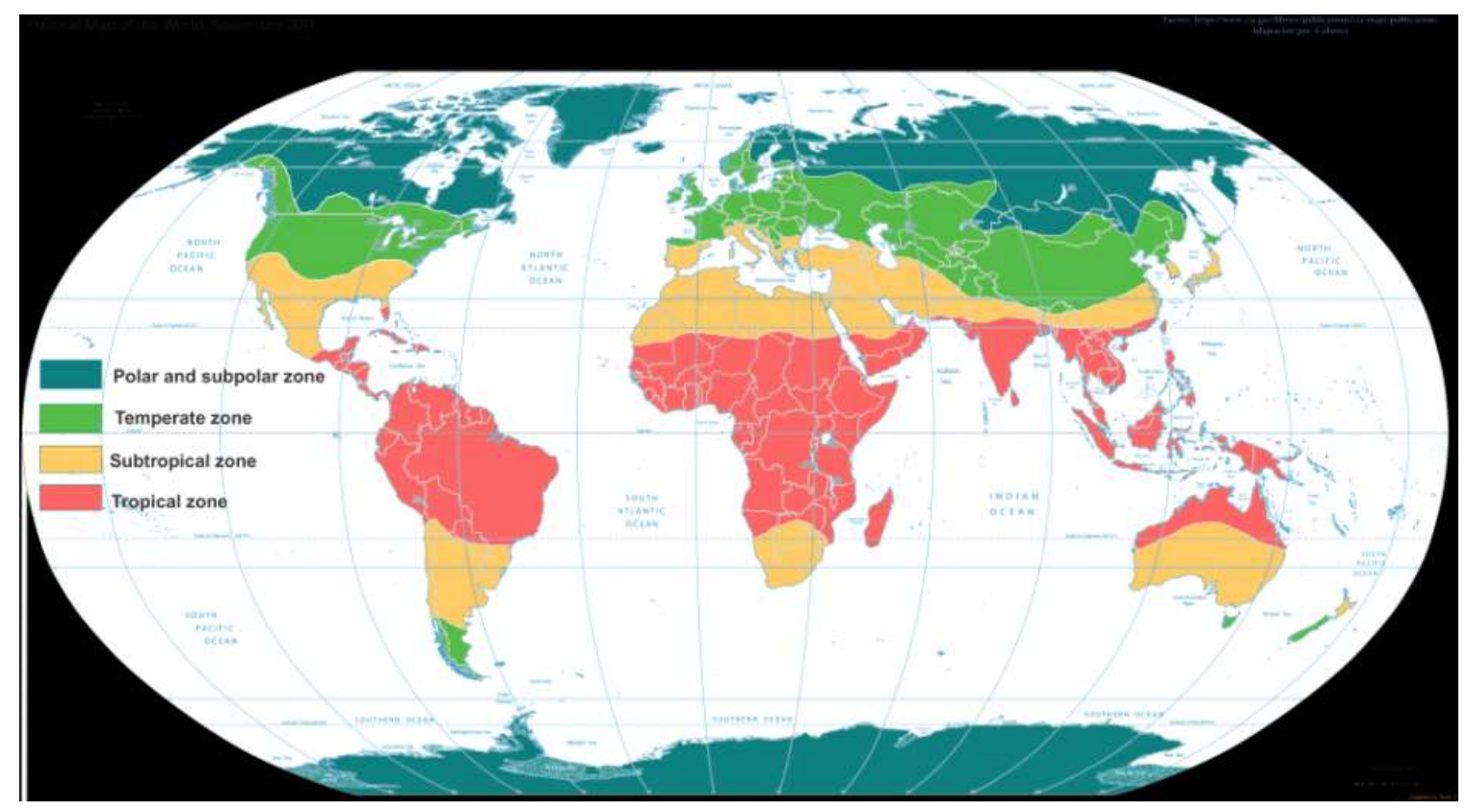

Figure 1: Major climate zones. 
The solar radiation reaches the ground on different parts of the Earth at different angles. On the equator, the sunlight reaches the ground almost perpendicularly, whilst at the poles, the angle of the Sun is lower or even under the horizon during the polar night. That explains why, in general, climate areas tend to be warmer towards the equator (tropical and subtropical) and cooler towards the poles (temperate and cold). Therefore, the temperatures in the agricultural non-climate zone (tropical and subtropical) are higher than in the temperate and cold climate zones [8].

\section{The Montreal Protocol and the Methyl Bromide Phase-Out}

\subsection{The Methyl Bromide and Its Uses}

MB is a broad-spectrum pesticide used to control soil-borne pathogens, insects, nematodes, and weeds. MB is used in the following areas: 1) Pre-plant fumigation of soil to control soil-borne pests and diseases in the production of some high-value crops, e.g., vegetables, ornamentals, tobacco, and strawberries; 2) Fumigation of some commodities and structures to control damaging pests, and 3) Quarantine and pre-shipment fumigation to prevent the spread of pests and diseases (Phytosanitary measures) (Figure 2). About 50 to 95\% of the MB bromide injected enters the atmosphere, contributing to the thinning of the ozone layer and allowing increased UV radiation to reach the Earth's surface, greatly impacting man and its environment [3].
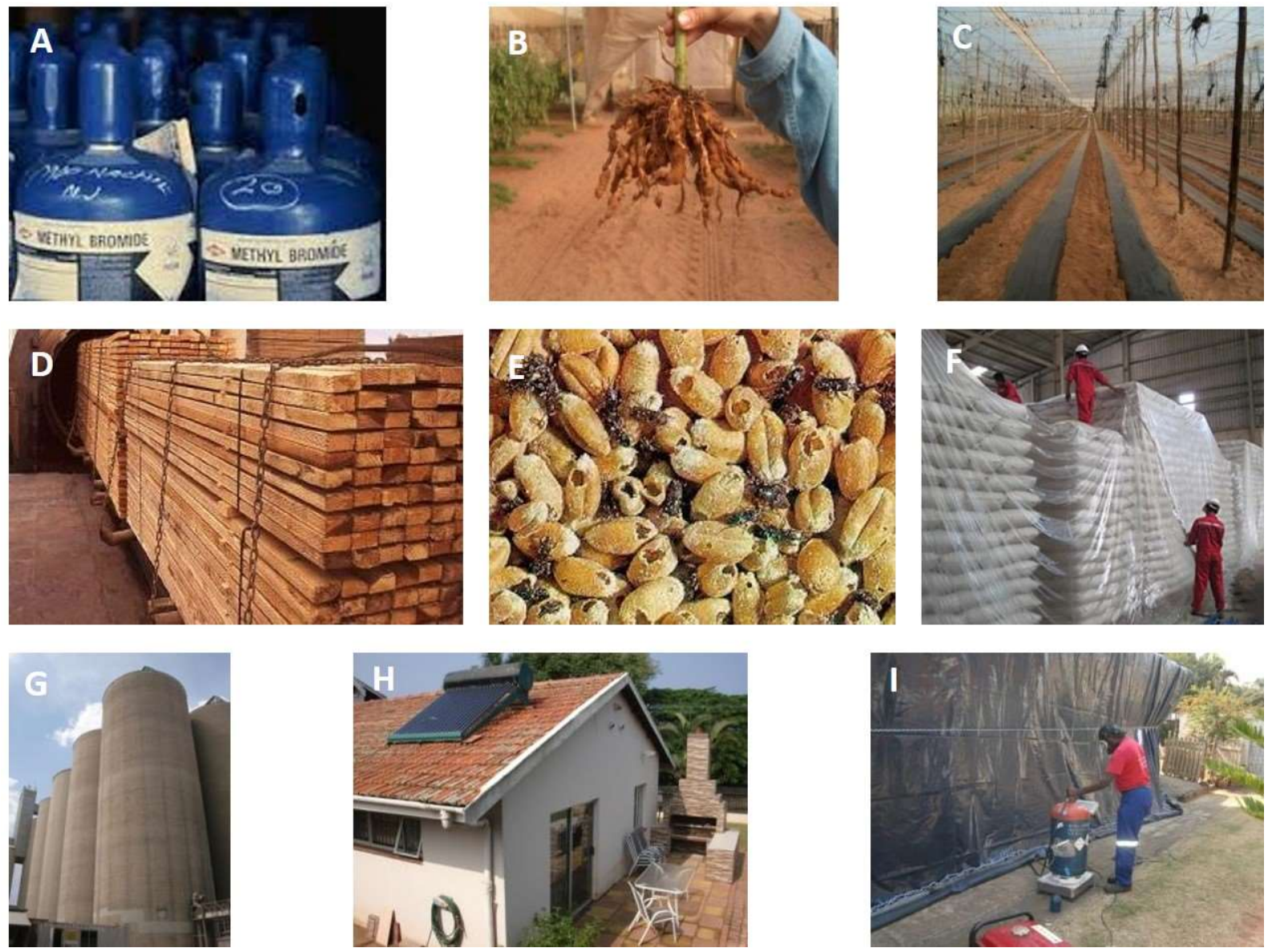

Figure 2. Soil (A, $B, C)$, commodities $(D, E, F)$, and structures $(G, H, I)$ fumigation with methyl bromide

\subsection{The Montreal Protocol}

In 1987, governments around the world agreed on the MP on substances that deplete the ozone layer (Chlorofluorocarbons (CFCs), Halons, Carbon tetrachloride, Hydrochlorofluorocarbons (HCFCs), Methyl chloroform, and Hydrobromofluorocarbons (HBFCs) to protect the man and its environment against depletion of the 
stratospheric ozone layer resulting from human activities. MB was added to the Protocol as an ozone-depleting substance in 1992 through the Copenhagen Amendment to the Protocol [7].

In 1997, the Parties to the MP agreed to accelerate the reduction in the controlled production and consumption of MB. The parties called for an MB phaseout by the year 2005 for developed countries (non-article 5 countries) and 2015 for developing countries (Article 5 countries), among which most are located in the nontemperate climate zone (Table $\mathbf{1}$ ).

Table 1: Methyl bromide phaseout schedules agreed at the ninth Meeting of the Parties in 1997.

\begin{tabular}{|c|c|c|}
\hline Year & Non-Article 5 Countries & Article 5 Countries \\
\hline \hline 1991 & Consumption/ production baseline & Consumption / production baseline \\
\hline 1995 & Freeze & \\
\hline $1995-98$ average & $25 \%$ reduction & Freeze \\
\hline 1999 & $50 \%$ reduction & Review of reductions \\
\hline 2001 & & $20 \%$ reduction \\
\hline 2002 & $70 \%$ reduction & Phaseout with provision for CUEs \\
\hline 2003 & Phaseout with provision for CUEs & \\
\hline 2015 & & \\
\hline
\end{tabular}

Source: UNEP, Ozone Secretariat, 2020[9].

Non Article 5 countries; Developed countries.

Article 5 countries; Developing countries, most of them are in the non-temperate climate zone.

\subsection{Implementation of alternatives to Methyl Bromide, including biofumigation, in non-temperate climate zone countries}

In 1990, the international community established a financial mechanism called the Multilateral Fund (MLF) to support efforts in developing countries to phase out ozone-depleting substances under the Montreal Protocol [10]. Contributions from industrialized countries finance the MLF, and projects are implemented by four agencies: the United Nations Environment Program (UNEP), the United Nations Development Program (UNDP), the United Nations Industrial Development Organization (UNIDO), and the World Bank. In some cases, projects have also been funded directly by non-A5 countries through bilateral cooperation and by the non-A5 parties themselves (government, agricultural producers) [11].

The projects have identified many economically and technically non-chemical and chemical alternatives (Table 2), which have often proved to be as efficient as MB, particularly when they are used as components of IPMs programs. In many projects conducted in Article 5 countries, biofumigation has been considered as a key alternative to MB (Table 2). This has often implied that growers and other users change their approach to crop production and pest control, including investments and training. Early phaseout of MB has proven beneficial to A5 parties in many instances by improving production practices, increasing the competitiveness of certain agricultural products in international markets, and training large numbers of growers, technical staff, and other key stakeholders [11].

\subsection{Biofumigation success stories in some non-temperate climate zone countries}

Biofumigation is a sustainable agronomic practice using naturally produced plant compounds to manage soil pests, including PPNs. This practice primarily relies on volatile organic compounds (VOCs) when they, or their byproducts, are incorporated into the soil. Many plants produce VOCs. However, the biofumigation practice is dominated by the use of glucosinolates (GSLs) that are hydrolyzed into isothiocyanates (ITCS), which are capable of 
killing or driving away PPNs [6]. In non-temperate zone countries, the biofumigant crop is grown as a cover crop and tilled into the soil at maturity, where it breaks down to release toxic compounds [4-6]. As previously reported, this SBPs control method is widely commercially used in many developing countries (Table $\mathbf{2}$ and Figure $\mathbf{3}$ ).

Table 2: Some multilateral funds projects considering biofumigation as an alternative to methyl bromide in nontemperate climate zone.

\begin{tabular}{|c|c|c|}
\hline Region & Country & Selected Alternatives \\
\hline \multirow{5}{*}{$\begin{array}{l}\text { Latin America } \\
\text { and } \\
\text { the Caribbean }\end{array}$} & Peru (Horticulture, tobacco) & Biofumigation, steam, solarisation, biological control, floating trays \\
\hline & Uruguay (Tomato, ornamentals) & Biofumigation, soilless, steam, grafting \\
\hline & Mexico (tomato, melon, strawberries, flowers) & Biofumigation, grafting, chemicals, IPM, steam, solarisation \\
\hline & $\begin{array}{l}\text { Argentina (tomato, tobacco, flowers, } \\
\text { strawberries) }\end{array}$ & $\begin{array}{l}\text { Biofumigation, chemicals (1, 3-D/Pic, MS, DMDS), steam, floating trays, } \\
\text { grafting }\end{array}$ \\
\hline & Costa Rica (Melon, cut flowers) & 1, 3-D/pic, metam sodium, solarisation, biocontrols, steam \\
\hline \multirow{3}{*}{ Africa } & $\begin{array}{l}\text { Morocco (vegetables, flowers, bananas, } \\
\text { strawberries) }\end{array}$ & Biofumigation, grafting, solarisation, steam, soilless, chemicals \\
\hline & Egypt (flowers, tomato, cucurbits) & Biofumigation, soilless, steam, grafting \\
\hline & Kenya (flowers) & Biofumigation, metam sodium, substrates, steam, grafting, IPM \\
\hline \multirow{4}{*}{$\begin{array}{c}\text { The Middle } \\
\text { East } \\
\text { and Asia }\end{array}$} & $\begin{array}{l}\text { Lebanon (ornamentals, vegetables, tobacco, } \\
\text { strawberries) }\end{array}$ & Biofumigation, fumigants, solarisation, grafting, floating trays \\
\hline & Jordan (tomato, cucurbits) & Biosolarisation, grafted plants, chemicals, biocontrol, steam, soilless, \\
\hline & $\begin{array}{l}\text { Turkey (tomato, cucurbits, flowers, pepper, } \\
\text { eggplant }\end{array}$ & $\begin{array}{l}\text { Biofumigation, grafting, metam sodium, 1, 3-D, 1, 3-D/Pic, dazomet, } \\
\text { solarisation, substrates, grafting, resistant varieties, steam, }\end{array}$ \\
\hline & China (tomato, cucurbits, strawberries, ginger) & Biofumigation, metam sodium, chloropicrin, 1, 3-D, grafting, biocontrol \\
\hline \multirow{2}{*}{ Europa CEIT } & Bosnia- Herzegovina (Tobacco, ornamentals) & Biofumigation, floating trays, solarisation \\
\hline & Macedonia (Tobacco, vegetables) & Biofumigation, floating trays, solarisation, dazomet \\
\hline
\end{tabular}

CEIT: Countries whose economy is in transition.

Adapted from MBTOC [11].

\subsection{The Montreal Protocol success in non-temperate and temperate zones countries}

From 2005 to 2018 (Figure 4), MP has reduced the production and consumption of MB by more than $99 \%$. This reflects the successful adoption of alternatives in the vast majority of sectors where MB was once used, both as a soil fumigant and as a postharvest or structural treatment [14].

\section{Success and Failure of Biofumigation in Managing Soil-Borne Pathogens in Some Non-Temperate Countries}

\subsection{Success of biofumigation}

Biofumigation success is influenced by many factors such as the pest complex, soil characteristics, type and availability of the soil amendment, and climatic conditions. Acceptable levels of suppression in PPN populations via biofumigation with brassica and non-brassica plant tissues have been demonstrated worldwide (in the open field and protected cultivation). It has been observed that biofumigation has the following effects [1,4-6,15-20].

- Decreases in nematode population in host roots and soil and change in their sex ratio;

- Reduces the nematodes severity expressed as root galling; 
- Increases the plant vigor, crop yield, and marketable production compared to fumigants treated plots (MB, 1, 3 D/Pic, Dazomet, MetamSodium, etc.);

- Increases of the beneficial microorganisms populations;

- Improves soil texture and structure and increases organic matter and water holding capacity;

- Is one of the least expensive alternatives to MB.

Argentina

Organic

amendments
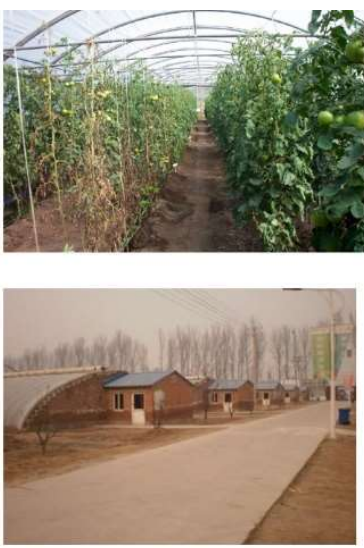

China

Chicken and straw

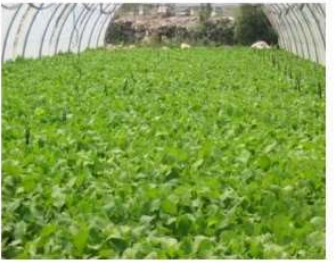

\section{Lebanon \\ Lettuce and \\ oil radish}

Mexico

Crop residues

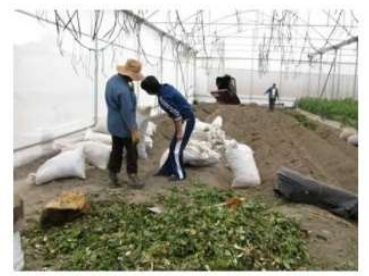

\section{Morocco}

Tagetes spp.

\section{Spain}

Crop residues and chicken manure
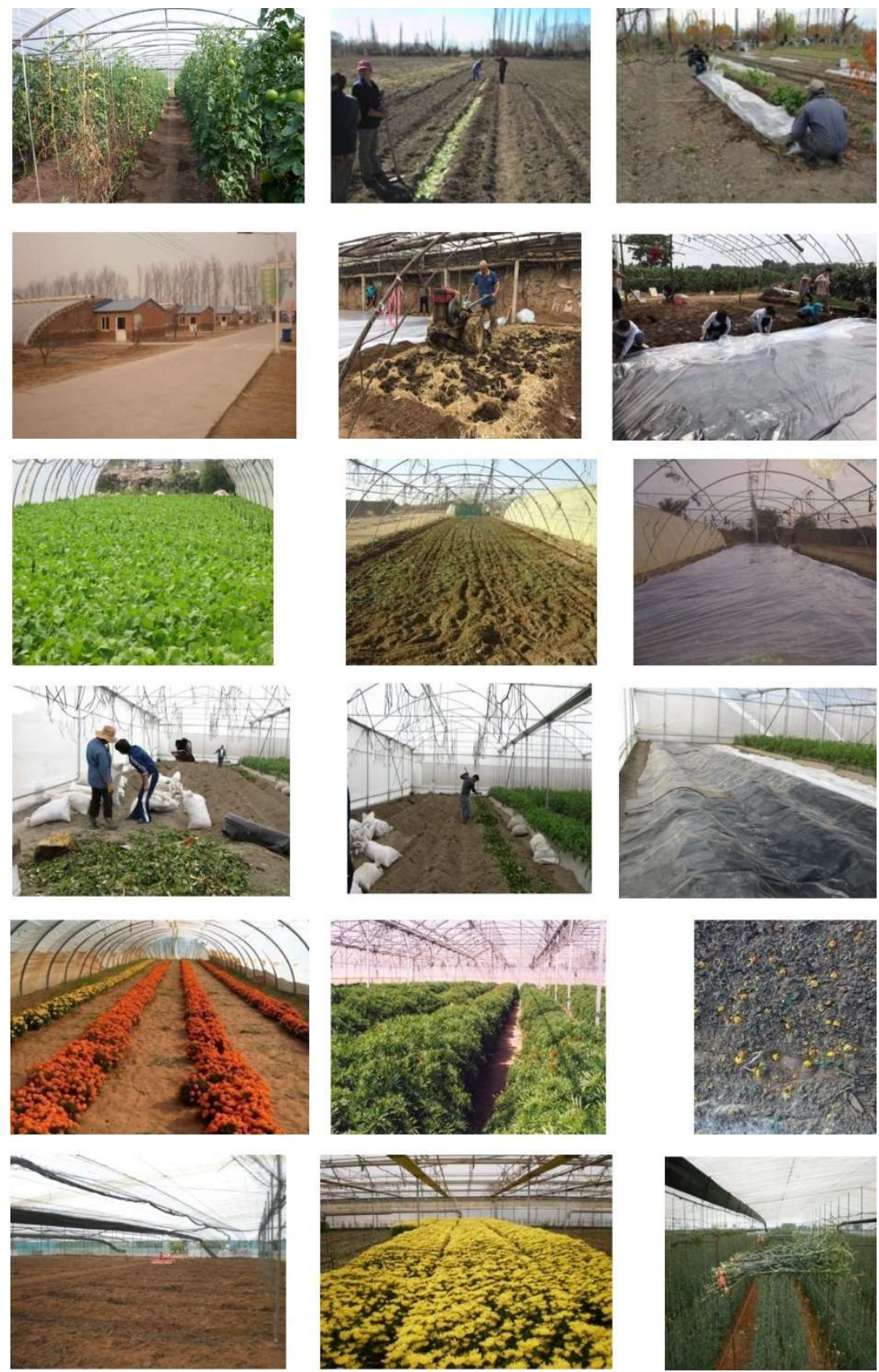

\section{Picture Sources:}

Argentina [12].

Picture 1: Control (left), biofumigation (right). Plants infected with Nacobbusaberrans, Fusarium solaniand Pyrenochaetalycopersici. Biofumigants: organic amendments (chicken manure, tomato, and pepper crop debris)

Pictures 2 and 3: Weed control using cabbage in spring for open field tomatoes.

China: Cao Aocheng, personal communication.

Mexico: [13].

Morocco, Spain, Lebanon: Besri's pictures.

Figure 3. Biofumigation in some non-temperate countries. 


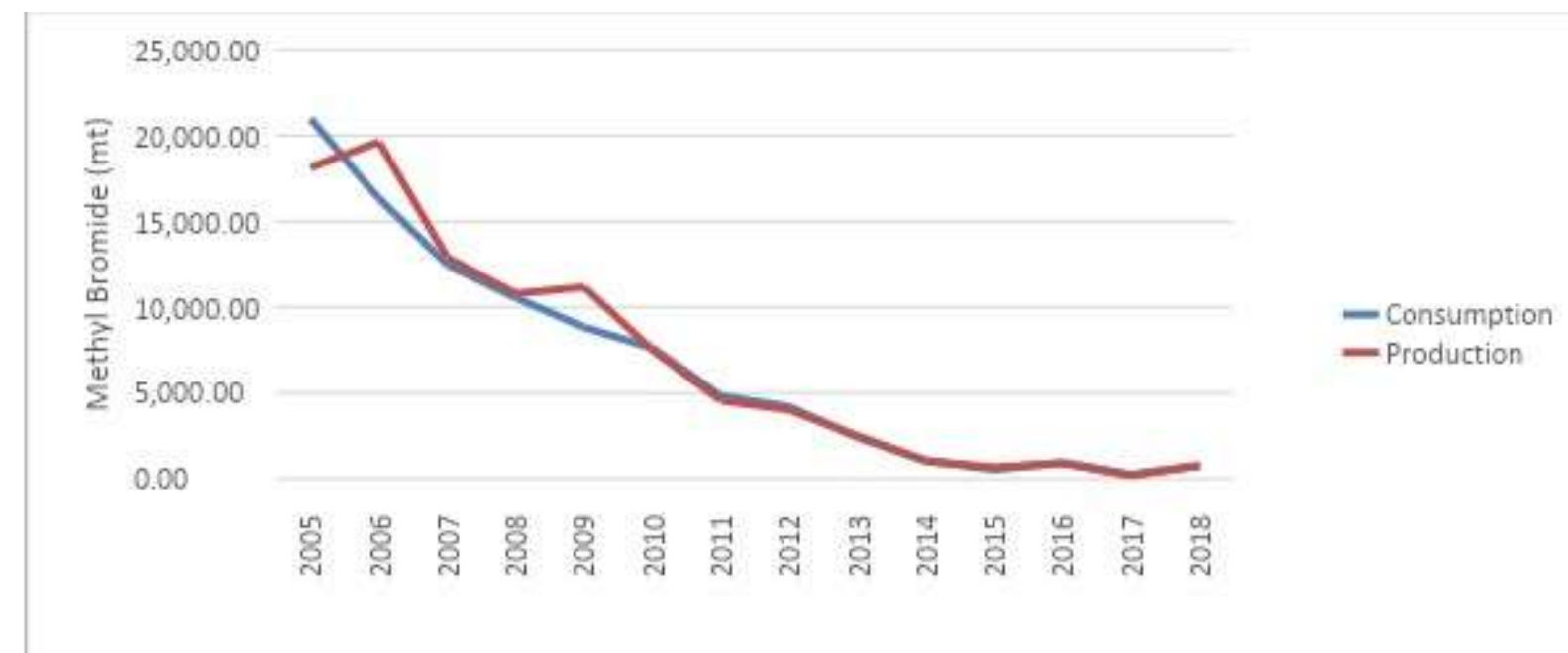

Figure 4. Controlled consumption vs. controlled production of MB (2005-2018).

\subsection{Failure of Biofumigation}

Reports on the inconsistency and inefficacy of biofumigation in suppressing SBPs under field and greenhouse conditions have also been reported. In some cases, insignificant or no reduction and instead increase in target SBPs level due to Brassica green manuring has been observed $[1,6]$.

Most of the economically important PPNs are known to infect a broad spectrum of cruciferous plants. Therefore, Brassicaceous plants can also serve as hosts to PPNs. Nematode populations surviving in deeper soil layers are unaffected by biofumigation, and those may serve as the reservoir inoculum for the next cropping cycle. Biocidal isothiocyanates (ITCS) have a half-life of a maximum of $10 \mathrm{~h}$ in soil. After soil incorporation of the biofumigation material into the soil, poor irrigation will not allow the transportation to the deeper soil layers of the fumigant compound and consequently prevents the faster volatilization of ITC or other compounds. Some studies failed to show any biofumigation effect because the soil was too dry, and the degree of biomass disruption was insufficient to maximize the ITC release. Some biofumigant plant materials are more effective against J2s (second stage juveniles) than against the egg masses of Meloidogyne spp. The active nematode stages are more vulnerable to the toxic volatiles emanating from decomposing brassica biomass [1,6,21-23]. Failure of biofumigation could also be due to the quality of the plastic used to cover the soil. Trapping of ITCS by polyethylene mulching permeable to methyl ITC [24] do not retain biocidal compounds. On the other hand, virtually impermeable films increase the efficacy of biofumigation [25].

This technology also presents some disadvantages, such as nutrient eutrophication and greenhouse gas (GHG) emissions. Moreover, an organic amendment is pathogenic and site-specific. An organic amendment suppressive to one pathogen could be ineffective, or even conducive, to other pathogens $[1,6,21,26,27]$.

\section{Combination of biofumigation with other control methods in some non- temperate countries: IPM}

Integrated Pests Management aims to reduce pest infestation by manipulating one or more of the biotic or abiotic components involved in the disease with minimal disturbance to the environment and natural resources $[28,29]$.

In temperate and non-temperate climate zones, biofumigation alone may not be adequate to replace soil fumigants, particularly MB. Biofumigation controls many soil-borne pathogens but does not completely eradicate them. Therefore, this technology should be combined with other chemical and non-chemical control methods, e. g. resistant varieties and rootstocks, solarisation, steaming, hot water, anaerobic soil disinfestations, microwaves etc. [30-34]. 


\subsection{Biofumigation and solarisation: Biosolarisation}

Covering the soil during the hot months of the summer increases soil temperatures, particularly in the hot non-temperate climate zone (subtropical and tropical countries) [35-39]. The combined action of organic amendment and solarization (often referred to as "Biodisinfestation" or "biosolarization") has shown its effectiveness to control PPN (Meloidogyne spp, Nacobbus aberrans, Helycotylenchus spp. Criconemella spp etc.) and fungal pathogens (Pyrenochaeta lycopersici, Fusarium solani, Sclerotium rolfsii, Sclerotinia sclerotiorum in many nonclimate temperate [40-43].

Lacasa et al. [44], Bello et al. [45] reviewed how Spain switched to biofumigation and bio-solarization as the main non-chemical alternative, followed by soilless cultivation, crop rotation, resistant varieties, and grafting. Nunez-Zofio et al. [46] reported that applying sugar beet vinasse followed by solarization reduced the incidence of Meloidogyne incognita in pepper crops while improving soil quality. In Italy, Gilardi et al. [47] developed a strategy to control Fusarium oxysporum f. sp. conglutinans and Fusarium oxysporum f. sp. raphani, causal agents of Fusarium wilt of rocket and basil, by combining amendments and soil solarization. An IPM strategy combining grafting and bio-solarisation to control Phytophthora capsici on bell pepper has also been developed [48]. In Turkey, biofumigation was efficiently applied in conjunction with solarisation [49]. In Macedonia, solarisation + biofumigation reduced root-knot nematodes and Fusarium spp population and gave the best tomato and cucumber yields [50]. Mitidieri et al. [51] reduced the incidence and severity of Nacobbus aberrans, Sclerotium rolfsii, Fusarium solani, and Pyrenochaeta lycopersici on tomatoes by combining biofumigation (chicken manure+broccoli) and solarisation.

\subsection{Biofumigation and antagonistic microorganisms}

Zakaria et al. [52], Li et al. [53], Wang et al. [54], Garcia-Raya and Michel [55], Jin et al. [56] reported that integrating biofumigation with antagonistic endophytic bacteria controls SBPs by regulating soil bacterial community structure and that the combined application of these microorganisms and biofumigation had superior efficacy against the SBPs compared with each treatment alone.

In Jordan, Biofumigation combined with Peacillomyces and Trichoderma reduced the population of Fusarium spp and Meloidogyne spp. populations and soil-borne pathogens and increased the cucumber yields [57].

In Egypt, Ghoname et al. [18] reported that bio-compost fortified with Trichoderma harzianum and Bacillus subtilis (disease suppressive compost) increased the lettuce head length, diameter, fresh weight, dry weight, total and marketable yield.

In Argentina, Perniolal et al. [58] reported that the antagonist fungus Trichoderma spp. is compatible with biofumigation and with Brassica juncea and Sinapis alba and that Azospirillum brasilense is only compatible with Sinapisalba and with low doses of Brassicajuncea.

\subsection{Biofumigation and grafting}

Grafting is widely used to control a wide spectrum of vegetables fungal soil-borne fungal pathogens (Fusarium, Verticilium, Pyrenochaeta, Monosporascus, Phytophthora, Pyrenochaeta,) nematodes (Meloidogyne spp.), viruses (CMV, ZYMV, PRSV, WMV-II, TYLCV), and bacteria (Ralstonia solanacearum). In addition, grafting improves plant yield and promotes plant vigor [59-68].

In Brazil, Zeist et al. [69] reported a beneficial effect of combining biosolarization with the addition of chicken manure and grafting in the control of bacterial wilt (Ralstonia solanacearum).

\subsection{Biofumigation and fumigants}

In China, Cao et al. [70], Zhang et al. [71] developed a new rotation model to reduce the application of fumigants and phase out MB in Hebei Province. This model was chloropicrin treatment one year, followed by biofumigation application the next year. Fusarium spp. and Phytophthora spp. were significantly reduced, and the 
yield significantly increased when rotating the two treatments.

In Lebanon, Haroutunian [72] evaluated the efficacy of two biofumigation crops, oil radish (Raphanus sativus oleifera) and arugula /rocket (Eruca vesicaria sativa), applied in combination with and without oxamyl in the management of the root-knot nematodes in greenhouse cucumber crops. The results have shown that incorporating oxamyl in the biofumigated soil does not increase the yield and does not reduce the nematode population. He concluded that oil radish and arugula as biofumigation crops with plastic cover could be considered an alternative management tool for the root-knot nematode in greenhouse cucumber production under Lebanese conditions.

\subsection{Biofumigation and multiple control methods: IPM}

In Mexico, Cristobal-Alejo et al. [73], Cid del Prado [13] and Franco Navarro et al. [74] developed an IPM program to control the false root nematode (Naccobus aberrans), including fertilization nematicide application (ethoprop), biological control, and biofumigation. It resulted in significant increases in plant height, dry foliage weight, stem diameter, and crop yield, as compared to other treatments. Pochonia chlamydosporia combined with nematicide application and environmentally friendly crop protection techniques that include incorporation of cabbage residues and composted manures has been recognised as a successful IPM tool for reducing N. aberrans populations.

In Morocco, Tagetes spp. is widely used as a component of an IPM program combining non-chemical (resistant cultivars and rootstocks), chemicals (metam sodium, 1, 3D/pic) to control SBPs attacking vegetable crops [30-32]. Integration of biofumigation with compost, solarisation, and grafting dramatically reduces the incidence of SBPS pathogens more than using each of these control methods used separately [75].

In Turkey, Ozturk et al. [49] reported that no single alternative (solarization, metam-sodium, 1,3 dichloropropene, dazomet, and biofumigation) could be recommended to replace MB. These control methods should be combined in an IPM program to manage soil-borne pests in Antalya conditions.

\section{Conclusion}

After phasing out of $\mathrm{MB}$, biofumigation has gained increasing attention as an option in the sustainable management of soil borne-pathogens attacking many crops both in climate and non-climate temperate countries. However, in some particular environmental conditions, biofumigation does not significantly reduce the incidence and severity of SBPs. In addition, biofumigation has the major disadvantage of requesting a relatively longer period of application time (45 days) as compared to MB (10 days). This fact alone is a major handicap for the widescale adoption of this technique as a viable alternative to MB for most farmers. Therefore, many researchers are increasingly interested in biofumigation to improve its efficiency and to:

- Reduce the application period of biofumigation crops;

- Identify appropriate species and cultivars of plants having a high amount of GSLs in their tissue and short vegetative period;

- Research the optimal doses of biofumigants to be used;

- Improve the incorporation methods and timing;

- Improve biofumigation both in an open field and in protected cultivation;

- Identify the optimal cultural practices for each plant: soil preparation, sowing dates, plant density, irrigation, fertilization, mulches, incorporation in the soil, etc.

- Identify the target nematode(s) and their host status on candidate biofumigant crop;

- Combine the biofumigant crop with other chemical and non-chemical control methods in an IPM program;

- Produce high-quality compost by using the large amounts of organic waste generated by horticulture; 
- Introduce the concept of biofumigation in the IPM training courses;

- Encourage MSC and PHDs research projects in biofumigation.

Research results will allow drafting regional practical guides on biofumigation, for non-temperate countries farmers, similar to the one edited by FAO to help Asian vegetable smallholders to adopt biofumigation as a soilborne pathogens control method [76].

In addition, most of the countries in the non-temperate climate zone, which are mostly developing countries, need to strengthen their collaboration with the industrialized ones by participating in their research, increasing exchanges of researchers and students and to be part of networks such as the Best4soil network, which is currently open only to European countries.

\section{Acknowledgements}

The author wishes to thank Prof. Cao Aocheng (China), Dr. Alejandro Valeiro, and Dr. Mariel Mitidieri (Argentina) for providing information on the current situation of biofumigation in their countries.

\section{References}

[1] Dutta TK, Khan MR, Phani V. Plant-parasitic nematode management via biofumigation using Brassica and non-Brassica plants: Current status and future prospects. Curr Plant Biol. 2019; 17: 17-32. https://doi.org/10.1016/j.cpb.2019.02.001

[2] Porter I, Pizano M, Besri M, Mattner S, Frazer P. Progress in the global phase out of methyl bromide and the relative effectiveness of soil disinfestation products to replace fumigation for pre-plant soil uses. Proceedings of the 7th International Symposium on Chemical and non-Chemical Soil and Substrate Disinfestation. Leuven, Belgium.13-18 September 2009. Acta Horticult. 2010; 883(25): Pages 59-66. https://doi.org/10.17660/ActaHortic.2010.883.4

[3] MBTOC. Methyl Bromide Technical Options Committee 2018.Assessment Report. UNEP, Nairobi.2019; 225 pp.

[4] Michel V. Ten years of biofumigation research in Switzerland. Aspects of Applied Biology 126. 5th International Symposium of Biofumigation, 2014; 1-10.

[5] Michel V, Urba K, Clarkson J. Green Manures and cover crops to reduce the pressure of soil-borne diseases in annual crops. In: Final report. Focus Group on Soil-borne diseases. October. Ed. EIP-AGRI, 2015; European Union. 1-5.

[6] Brennan RJ, Glaze-Corcoran S, Wick R, Hashemi M. Biofumigation: An alternative strategy for the control of plant-parasitic nematodes. J Integrat Agricul. 2020; 19(7): 1680-1690. https://doi.org/10.1016/S2095-3119(19)62817-0

[7] Batchelor TA. International and European Community control on methyl bromide and the status of methyl bromide use and alternatives in the European Community. In: Proc. International Conference on Alternatives to Methyl Bromide. 5-8 March 2002; Sevilla. Office for Official Publications of the European Communities: Luxembourg. 2002; pp. 35-39.

[8] Koop F. 2020; What are the different climate zones? A simple explainer.https://www.zmescience.com/other/feature-post/climatezones-explainer/

[9] UNEP Ozone Secretariat. Montreal Protocol Handbook, 2020, 14 the edition. .https://ozone.unep.org/sites/default/files/Handbooks/ MP-Handbook-2020-English.pdf

[10] Luken R, Tamas GT. The Montreal Protocol's multilateral fund and sustainable development. Ecol Econom. 2006; 56: $241-255$. https://doi.org/10.1016/j.ecolecon.2004.04.013

[11] MBTOC. Report of the Methyl Bromide Technical Options Committee. 2014 Assessment. UNEP, Nairobi, Kenya, $2015 ;$ pp. 277.

[12] Mitidieri MS, Peralta R, Barbieri M, Brambilla V, Piris E, Sasía F, Obregón V, Vasquez P A, Iriarte L, Reybet G, Barón C. Biofumigation experiences in Argentina 2017; https://cdn.harper-adams.ac.uk/document/page/2_Biofumigation-Experiences-in-Argentina.pdf

[13] Cid del Prado Vera. Biofumigation experiment Greenhouse tomatoes Texcoco, Mexico, 2019. in: Nacobbus aberrans, 2019; http://nemaplex.ucdavis.edu/Taxadata/G085s1.aspx)

[14] TEAP Report of the Technology and Economic Assessment Panel, Progress report, UNEP, Nairobi, Kenya. 2020; 1 : 112 pp Available at https://ozone.unep.org/science/assessment/teap

[15] Wang D, Yang Zi, Qiao, Kang, Yuan R, Yao X, Hu X, Li S. Effects of Bio Fumigation on Inhibition of cucumber Fusarium wilt, quality and yield of cucumber. Chinese Agricultural Science Bulletin. 2016; 32(28):125-130. https://doi.org/10.1360/N972015-00951

[16] Li S, Zheng C, Zhang R, Yang Z, Qu H, Liu T, Yuan R, Yao X, Wang X, Xu N, Zhang C. Effect of biofumigation on yield and Verticillium wilt incidence of continuous eggplant in greenhouse. Journal of Northeast Agricultural University, 2017; 48(5): 35 41.

[17] Fourie H, Ahuja P, Lammers J, Daneel M. Brassicacea-based management strategies as an alternative to combat nematode pests: a synopsis, Crop. Prot. 2016; 80: 21-41. https://doi.org/10.1016/j.cropro.2015.10.026 
[18] Ghoname AA, Riad GS, Abdel Mohsen M, El-Bassiony AM, Tantawy AS. Biofumigation with Fresh Manure or Brassicaceae Residuals could be a Promising Methyl Bromide Alternative in Head Lettuce Production. 2017; Cross ref DOI link: https://doi.org/10.1007/s10343-017-0384-x https://doi.org/10.1007/s10343-017-0384-x

[19] Ikeda K, Banno S, Fujimura M. Suppressive effect of incorporation of on-site cultivated Indian mustard (Brassica juncea) on Verticillium wilt of eggplant. Soil Microorganisms, 2017; 71(2): pp 44-48.

[20] Gilardi G, Cucu MA, Pugliese M, Lodovica Gullino M, Garibaldi A. Effect of different organic amendments on lettuce Fusarium wilt and on soil-borne microorganisms. Proceedings of the IXth international symposium on soil and substrate disinfestation. Heraklion, Greece, 9-13 September 2018; P 17.

[21] Michel V, Lazzeri L. Green manures and organic amendments to control the corky root of tomato. Acta Hort. (ISHS) 2010; 883: 287294. https://doi.org/10.17660/ActaHortic.2010.883.35

[22] Bangarwa SK, Norsworthy JK, Mattice JD, Gbur EE. Yellow nutsedge interference in polyethylene-mulched bell pepper as influenced by turnip soil amendment. Weed Technol. 2011; 25: 3. https://doi.org/10.1614/WT-D-10-00120.1

[23] Mashela P, Pofu K, Nzanza B. Suitability of Brassica oleracea leaves in managing Meloidogyne incognita through the ground leaching technology system under micro plot conditions. Acta Agriculturae Scandinavica, Section B. Soil \& Plant Science 2013; 63(1): 19-24. https://doi.org/10.1080/09064710.2012.711351

[24] Austerweil M, Steiner B, Gamliel A. Permeation of soil fumigants through agricultural plastic films, Phytoparasitica, $2006 ; 34: 491-501$. https://doi.org/10.1007/BF02981205

[25] Oz H, Coskan A, Atilgan AJ, Determination of effects of various plastic covers and biofumigation on soil temperature and soil nitrogen form in greenhouse solarization: new solarization cover material. Journal of Polymers and the Environment 2017; 25: 370-377. https://doi.org/10.1007/s10924-016-0819-y

[26] Lopez A, Lacasa A, Guirao P, Hernendez F. Non-chemical alternatives to methyl bromide in greenhouse-grown sweet pepper in Spain. Proc. International Conference on Alternatives to Methyl Bromide. 5-8 March 2002; Sevilla. Office for Official Publications of the European Communities: Luxembourg. pp. 280-282

[27) Oka Y. Mechanisms of nematode suppression by organic soil amendments: A review. In: Applied Soil Ecology, 2010; 44: 101-115. https://doi.org/10.1016/j.apsoil.2009.11.003

[28] Katan J. Integrated pest management in connection with soil disinfestation. Acta Hort. 2014 ; 1044: $19-28$. https://doi.org/10.17660/ActaHortic.2014.1044.1

[29] Gamliel A. Application of soil disinfestation in the view of system approach: a bottleneck or a tool for improvement? Acta Hort. (ISHS) 2014; 1044: 245-25. https://doi.org/10.17660/ActaHortic.2014.1044.29

[30] Besri M. Leading Methyl Bromide alternatives in commercial use for tomato production in different geographic regions except the United States. Proceedings of the Fifth International Conference on Alternatives to Methyl Bromide. Lisbon. Portugal. 27-30 September 2004; 127-131.

[31] Besri M. Methyl bromide Phase out in Morocco: Current situation and future challenges. Proceedings of the Regional Consultative Meeting for Methyl Bromide Experts in Africa. Nairobi, Kenya, 2011; 13-15 April 2011.

[32] Besri M. Leading Methyl Bromide Alternatives in Commercial Use for vegetable Production in Different Geographic Regions and particularly in the Mediterranean area. Proceedings of "A Global Policy and Technical Workshop on Methyl Bromide. Towards a successful total phase-out of methyl bromide before January 1, 2015: Approaches and Challenges". 23-25 February 2014; (Sharm ElSheikh, Egypt).

[33] Vintila M, Craciun S, Popescu P, Bogoescu M. Microwave energy system used for soil disinfestations. Proceedings of the IXth international symposium on soil and substrate disinfestation. Heraklion, Greece, 9-13 September 2018; P 80.

[34] Castellá-Lorenzo G, Savigliano R, Pizano M. Breaking the bondage to methyl bromide in agriculture. UNIDO experience. Acta Hort. (ISHS) 2014; 1044: 281-287. https://doi.org/10.17660/ActaHortic.2014.1044.35

[35] Stapleton J, Duncan RA. Soil disinfestation with cruciferous amendments and sublethal heating: effects on Meloidogyne incognita, Sclerotium rolfsiiand Pythium ultimum. Plant Pathol. 1998; 47: 737-742.

[36] Ploeg AT, Stapleton J. Glasshouse studies on the effects of time, temperature, and amendment of soil with broccoli plant residues on the infestation of melon plants by Meloidogyne incognita and M. javanica, Nematology 2001; 3: 855-861. https://doi.org/10.1163/156854101753625353

[37] Besri M. Solarization of soil and agricultural materials for control of Verticillium wilt and Didymella stem canker in Morocco. In: Soil solarization. Katan J. and DevayJ E., Eds, CRS press. 1991; pp. 237243.

[38] Besri M. Soil solarisation as an alternative to Methyl Bromide for the control of Broomrape (Orobancheramosa) in vegetables under greenhouse conditions. Proceedings of the international research conference on methyl bromide alternatives and emissions reductions, December 7-9, 1998; Orlando, Florida, 51A-1.

[39] Besri M, Pizano M, Porter I, Solarisation and the methyl Bromide Crisis. In: Soil Solarization: Theory and Practice., Katan Jand Gamliel A, eds. Academic Press, 2012; 77-87: 266 pp. https://doi.org/10.1094/9780890544198.011

[40] Kanaan H, Raviv M, Medina SH, Krassnovsky AD, Minz D. The effects of solar disinfestation and compost maturation level on soil microbial activity and eradication of Macrophominaphaseolina and Verticillium dahliae. Acta Horticulture 2014; 1044: VIII 
International Symposium on Chemical and Non-Chemical Soil and Substrate Disinfestation. https://doi.org/10.17660/ ActaHortic.2014.1044.18

[41] Klein E, Katan J, Gamliel A. Soil suppressiveness to Meloidogyne javanica as induced by organic amendments and solarization in greenhouse crops.Crop Protection, 2012; 39: 26-32. https://doi.org/10.1016/j.cropro.2012.02.013

[42] Mitidieri M, Brambilla V, Barbieri M, Piris E, Arpía E, Celié R, Peralta R, Ferrari M. Efecto de la biosolarización y fertilización con cianamida cálcica en la producción bajo cubierta de tomate (Solanumesculentum) en San Pedro, Buenos Aires. XXXVIII Congreso Argentino de Horticultura, 5-8 October 2015. Horticultura Argentina. 2015; 34: 85.

[43] Mitidieri MS, Brambilla MV, Barbieri MO, Piris E, Celié R, Paunero I, Arpía E. Tratamientos combinados de biosolarización y cianamida cálcica en un invernadero hortícola. 2017http://inta.gob.ar/documentos/tratamientos-combinados-de-biosolarizacion-y-cianamidacalcica-en-un-invernadero-horticola.

[44] Lacasa A, Guerrero MM, Guirao P, Ros C Alternatives to methyl bromide in sweet pepper crops in Spain. Proc. International Conference on Alternatives to Methyl Bromide. 5-8 March 2002; Sevilla. Office for Official Publications of the European Communities: Luxembourg. pp 187-192.

[45] Bello A, Lopez-Perez JA, Garcia-Alvarez A, Sanz R, Lacasa A. Biofumigation and nematode control in the Mediterranean region, in: Cook R.C., Hunt D.J., Eds., Proceedings, IV.International Congress of Nematology, 2004; 133-149.

[46] Nunez-Zofio M, Larregla S, Garbisu C, Guerrero MM, Lacasa C M, Lacasa A. Application of sugar beet vinasse followed by solarization reduces the incidence of Meloidogyne incognita in pepper crops while improving soil quality. Phytoparasitica, 2013. 41.2. 181-191. https://doi.org/10.1007/s12600-012-0277-6

[47] Gilardi G, Demarchi S, Moizio M, Gullino ML. and Garibaldi A.Disease management strategies against Fusarium wilt of basil and rocket by combining amendments and soil solarization. Acta Hort. (ISHS) 2014; 1044: 319-324. https://doi.org/10.17660/ ActaHortic.2014.1044.41

[48] Gilardi G, Pugliese M, Colla P, Gullino ML, Garibaldi A. Management of Phytophthora capsici on bell pepper and Colletotrichum coccodeson tomato by using grafting and organic amendments. Acta Hort. (ISHS) 2014; 1044: 257-262. https://doi.org/10.17660/ ActaHortic.2014.1044.31

[49] Ozturk A, Yilmaz S, Kececi M, Unlu A, Deviren A, Zcelik A, Cetinkaya S; Cevri H, Akkaya F, Ozkan CF. Alternatives to methyl bromide for tomato and cucumber production in Turkey. Proceeding of Alternatives to Methyl Bromide. Sevilla, Spain. 2002; pp. $209-214$.

[50] Popsimonova G. Non-chemical alternatives to methyl bromide used in Macedonia on vegetables. Proc. International Conference on Alternatives to Methyl Bromide. 5-8 March 2002, Sevilla. Office for Official Publications of the European Communities: Luxembourg. pp. 299-301.

[51] Mitidieri M; Brambilla V, Saliva V, Piris E, Piris M, Celié R, Pereyra C, Del Pardo K, Chaves E, González J. Effect of different biofumigation treatment sequences on physico-chemical and biological soil parameters and on tomato and lettuce yields undercover. Horticultura Argentina. 2009; 28: 5-17 (in Spanish).

[52] Zakaria HM, Kassab AS, Shamseldean MM, Oraby MM, El-Mourshedy MMF. Controlling the root-knot nematode, Meloidogyne incognita in cucumber plants using some soil bioagents and some amendments under simulated field conditions. Annals of Agricultural Sciences 2013; 58(1): Pages 77-82. https://doi.org/10.1016/j.aoas.2013.01.011

[53] Li GJ, Dong QE, Ma L, Huang Y, Zhu ML, Ji YP, Wang QH, Mo MH, Zhang KQ. Management of Meloidogyne incognita on tomato with endophytic bacteria and fresh residue of Wasabia japonica. Journal of Applied Microbiology, 2014; 117: $1159-1167$. https://doi.org/10.1111/jam.12590

[54] Wang Q J, Ma Y, Wang GF, Gu ZG, Sun D, An X, Chang ZZ. Integration of biofumigation with antagonistic microorganisms can control the Phytophthora blight of pepper plants by regulating soil bacterial community structure. In: European Journal of Soil Biology. 2014; 61: 58-67. https://doi.org/10.1016/j.ejsobi.2013.12.004

[55] Garcia-Raya P, Michel V. Combined use of organic biofumigant materials and a biological control agent: First experience in Switzerland. In: Future IPM 3.0 towards a sustainable agriculture. 19th October, Ed. IOBC-WPRS, Riva del Garda, Italy. $2017 ; 1$.

[56] Jin N, Lu X, Wang X. The effect of combined application of Streptomyces rubrogriseus HDZ-9-47 with soil biofumigation on soil microbial and nematode communities. Sci Rep. 2019. 9, 16886. https://doi.org/10.1038/s41598-019-52941-9

[57] Al-Zubi MF. Non-chemical alternatives to methyl bromide use in Jordan Proc.International Conference on Alternatives to Methyl Bromide. Sevilla. Office for Official Publications of the European Communities: Luxembourg, 5-8 March 2002; pp. $291-295$.

[58] Perniolal OS, Chorzempa SE, Staltari S, Marta Mónica A, Gassó MM, Galian LR, del Carmen Molina M. Biofumigación con Brassicajuncea L. Czerniak y Sinapis alba L. Acción sobre el crecimiento in vitro de Trichodermaspp. y Azospirillumbrasilense Tarrand, Krieg et Döbereiner. Rev. Protección Veg. 2016; 31(1): 57-62.

[59] Yilmaz S, Celik I, Zengin S. Combining effects of soil solarisation and grafting on plant yield and soil-borne pathogens in cucumber. International Journal of Plant Production, 2011; 5(1): 95-104.

[60] Foster JM, Naegele RP. Evaluation of Eggplant Rootstocks and Pepper Varieties for Potential Resistance to Isolates of Phytophthora capsici from Michigan and New York. Crop protection, 2013; 97(8): 1037-1041. https://doi.org/10.1094/PDIS-06-12-0562-RE

[61] Keinath AP, Hassell RL. Control of Fusarium Wilt of Watermelon by Grafting onto Bottle gourd or Interspecific Hybrid Squash Despite Colonization of Rootstocks by Fusarium. Plant Diseases, 2014; 98: 255-266. https://doi.org/10.1094/PDIS-01-13-0100-RE 
[62] Besri M. Current situation of tomato grafting as an alternative to Methyl Bromide for Tomato production in Morocco. Proceedings of the international research conference on methyl bromide alternatives and emissions reductions, October 29- November 1, 2007; 2007b. San Diego, California, 62-1, 62-5.

[63] Besri M. New development with tomato grafting as alternatives to Methyl Bromide in Morocco. Journal of Plant Pathology, 2008; 90: 402.

[64] Besri M. Cucurbits grafting as an alternative to methyl bromide for cucurbits production in Morocco, 2008: Proceedings of the international research conference on methyl bromide alternatives and emissions reductions, November 11-14, Orlando, Florida.

[65] Besri M. Economical aspects of grafting tomato in some Mediterranean countries. Proceedings of the international research conference on methyl bromide alternatives and emissions reductions, October 29- November 1, 2007; San Diego, California, 59-1, 595 .

[66] Louws FJ, Rivard CL, Kubota C. Grafting fruiting vegetables to manage soil-borne pathogens, foliar pathogens, arthropods, and weeds. Scientia Horticulturae. 2010; 127. 127-146. https://doi.org/10.1016/j.scienta.2010.09.023

[67] Schwarz D, Rouphael Y, Colla G, Venema JH. Grafting as a tool to improve tolerance of vegetables to abiotic stresses: Thermal stress, water stress, and organic pollutants. Scientia Horticulturae 2010; 127: 162-171. https://doi.org/10.1016/j.scienta.2010.09.016

[68] Khiareddine HJ, Ben Abdallah RA, Daami-Remadi M, Nefzi A, Ayed A. Grafting Tomato Cultivars for Soil Borne Disease. Suppression and Plant Growth and Yield. J Plant Pathol Microbiol 2019; 10(1): 1-8. https://doi.org/10.18393/ejss.556780

[69] Zeist AR, Resende JTV, Pozzebon BC, Gabriel A, Silva AA, Zeist RA. Combination of solarization, biofumigation, and grafting techniques for the management of bacterial wilt in tomato. Horticultura Brasileira. 2019; 37: 260-265. DOI - http://dx.doi.org/10.1590/S0102$053620190302 \mathrm{https} / / /$ doi.org/10.1590/s0102-053620190302

[70] Cao A. Rotating chloropicrin fumigation and biofumigation to control strawberry soil-borne diseases. Proceedings of the IXth international symposium on soil and substrate disinfestation. Heraklion, Greece, 9-13 September 2018; P 28.

[71] Zhang D, Yan D, Fang W, Huang B, Wang X, Zhu J, Liu J, Ouyang C, Li Y, Wang Q, Cao A. Chloropicrin alternated with biofumigation increases crop yield and modifies soil bacterial and fungal communities in strawberry production. Science of the Total Environment. 2019; 675: 615-622. https://doi.org/10.1016/j.scitotenv.2019.04.222

[72] Haroutunian G. The use of biofumigation crops as an alternative to Methyl Bromide for the management of the root-knot nematode in greenhouse cucumber production. Agronomy. 2013; Agro Paris-Tech.

[73] Cristóbal-Alejo J, Mora-Aguilera G, Manzanilla-López RH, Marbán-Méndoza N, Sánchez-Garcia P, del Prado-Vera IC, Evans K. Epidemiology and integrated control of Nacobbus aberrans on tomato in Mexico. Nematology, 2006; 8(5): $727-737$. https://doi.org/10.1163/156854106778877929

[74] Franco-Navarro F, Velasco-Azorsa R, Cid del Prado-Vera I. Pochoniachlamydosporia vs Nacobbus aberrans: experiences in the control of the false root-knot nematode in Mexico. Journal of Nematology, 2016; 48: 322.

[75] Besri M. Use of Marigolds (Tagetesspp) as a cover crop for the control of tomato root-knot nematodes (Meloidogynespp) in Morocco. Proceedings of the international symposium on biofumigation 7, Plants for Soil Health, Michel V., editor, 22-26 March 2021; Switzerland (in Press).

[76] Kumar P. Biofumigation, concept note, and compilation of session guides on biofumigation. FAO, 2005. 